\section{Shrub facilitation of Quercus ilex and Quercus pubescens regeneration in a wooded pasture in central Sardinia (Italy)}

\begin{abstract}
Alias S ${ }^{(1)}$, Bianchi L ${ }^{(2)}$, Calamini $\mathrm{G}^{(2)}$, Gregori E ${ }^{(3)}$, Sioni S ${ }^{(2)}$
In the woodlands of Sardinia, as in many other areas of the Mediterranean region, grazing of domestic animals is still very common, though often in the absence of any sustainable management logic or technique. The present work analyzes the effects of excessive grazing pressure on a wooded pasture in the municipality of Orgosolo (Nuoro province), emphasizing the effects on the natural regeneration of the oak species (Quercus ilex and Quercus pubescens). This study has revealed the positive effects of the interaction between shrubs and seedlings of tree species. Crataegus monogyna proved to be the most efficient shrub species in favouring the establishment and growth of saplings; Rubus ulmifolius is efficient in the establishing phase but somewhat less so in the following stages. The other shrub species (Prunus spinosa, Genista pichisermolliana, Stachys glutinosa) play a lesser facilitating role. Despite the fact that seedlings are found in more than half $(56 \%)$ of the shrub patches, the average age of the seedlings $(14 \pm 0.6 \mathrm{yrs})$ and their small average size (height $24 \pm 1.4 \mathrm{~cm}$ ) lead to think that the present grazing pressure is incompatible with any concrete chance of success for their natural regeneration.
\end{abstract}

Keywords: Shrub facilitation, Tree regeneration, Wood pasture management, Overgrazing, Quercus ilex, Quercus pubescens

\section{Introduction}

Pastures with consistent tree cover, composed mostly of evergreen oaks like Quercus ilex, Quercus rotundifolia and $Q$. suber, are quite widespread in Western Mediterranean countries. These landscapes assume a peculiar physiognomy and are called "dehesa" in Spain and "montado" in Portugal. The same stands are also present in Italy, especially on the island of Sardinia.

The features and functions of these formations are the result of specific climatic conditions, from somewhat mild summer droughts, combined with grazing and related human activities over the centuries to exploit natural resources (Perevolotsky \& Seligman

(1) University of Sassari, v. Sa Terra Mala, I-08100 Nuoro (Italy); 2) Department of Environmental Forestry Science and Technology, University of Florence, v. San Bonaventura 16, I-50145 Florence (Italy); (3) CRA - ABP Florence, p.zza M. D’Azeglio 30, I50121 Florence (Italy)

\section{(a) Livio Bianchi (livio.bianchi@unifi.it)}

Received: Mar 02, 2009 - Accepted: Sep 24, 2009

Citation: Alias S, Bianchi L, Calamini G, Gregori E, Sioni S, 2010. Shrub facilitation of Quercus ilex and Quercus pubescens regeneration in a wooded pasture in Central Sardinia (Italy). iForest 3: 16-22 [online: 2010-0122] URL: http://www.sisef.it/iforest/ show.php?id=517
1998, Peco et al. 2006, Linares 2007). What we are looking at today must therefore be considered a peculiar agro-forestry system (Joffre et al. 1988), rather than the remains of a previously closed forest ecosystem.

Today, a general tendency for overgrazing with progressive symptoms of degradation can be observed (Pulido et al. 2001, Plien2004, Dufour-Dror 2007). In particular, the open woods of the meso-Mediterranean belt dominated by the Holm oak, maintain their functionality only with low grazing pressure. High livestock densities produce negative effects, especially on the natural regeneration of the tree component (Cierjacks \& Hensen 2004), which is often confined under the protective shadow of shrubs which are not palatable to the animals. These patches then become potential safe sites for seedlings and saplings as recognized by many authors 1992, Callaway \& Davis 1998, Rousset \& Lepart 1999, Gómez et al. 2001, Kuiters \& Slim 2003, Bakker et al. 2004, Smit et al. 2005, Smit et al. 2007).

In the majority of the hilly and mountain areas of Sardinia, continuous stocking is the main grazing method (Camarda 1993). This is true also for the Pradu woodland, which is the subject of the present study. In recent decades, the pastoral activity in Mediterranean areas has been subjected to important modifications, with increasing livestock inger et al. 2004, Plieninger 2005, Munoz (Callaway \& D’Antonio 1991, Callaway density and the shift from transhumance to more stable and intensive forms of breeding. The Pradu woodland has also experienced these transformations, together with a considerable increase in the number of animal species feeding at the same time (cattle and horses have joined the more traditional herds of sheep, goats and swine). As a result, the natural regeneration of the tree component has sharply decreased in density and spatial distribution, failing to overcome the progressive senescence of the existing stand under natural or human-induced stresses (Pulido et al. 2001, Diaz et al. 2003). The conservation of the Pradu woodland is further compromised by the increasing, uncontrolled harvest of large branches, and even entire trees, for fuel (Alias et al. 2008).

This paper aims to quantify the consistence and potential of natural tree regeneration at the Pradu site, by analyzing in detail the characteristics of the shrub components, with respect to their ability to become nurse plants for tree saplings.

\section{Material and Methods}

\section{Study area}

The study was conducted in mid-eastern Sardinia in the municipal territory of Orgosolo (Nuoro province) in a part of the Pradu woodland (N 40 $10^{\prime}$; E $9^{\circ} 20^{\prime}$ ) with an area of about 280 ha at an altitude of about $1000 \mathrm{~m}$ above sea level, with a mostly western exposure.

The climate, according to the bioclimatic classification of Rivas-Martínez \& RivasSáenz (2008), is mid-Mediterranean with an oceanic footprint and an average yearly temperature and rainfall of $12{ }^{\circ} \mathrm{C}$ and $1100 \mathrm{~mm}$ respectively (Bianchi et al. 2003).

Paleozoic intrusive rocks dominate the landscape, with outcrops of granite and filladic schists (Madrau 1995). Dystric, Typic and Lithic Xerorthens (Soil Survey Staff 2006) are the more common soil types over both intrusive and metamorphic substrates; they are usually shallow, coarse-textured, rich in rock fragments and with quite a low content of organic matter. Typic and Lithic Dystroxerepts have limited diffusion over more gentle slopes and in concavities. Despite the generally good soil permeability, recent gully phenomena may be observed locally.

Vegetation type refers to the climax of Sardinian mountain forests dominated by Holm oak and Downy oak stands (Arrigoni 1968). The tree component of the vegetation consists of a high forest with an unevenly aged structure (the diameter ranges from 40$160 \mathrm{~cm}$ ) where Holm oak (Quercus ilex) is the dominant species (96\%), and Downy oak (Quercus pubescens) (3\%) and Montpellier 
maple (Acer monspessolanum - 1\%) the associated species. The average density is 65 trees per hectare, but the spatial distribution is very irregular with scarcely covered (minimum of 11 plants $\mathrm{ha}^{-1}$ ) and densely covered (121 plants ha $\left.{ }^{-1}\right)$ areas. Historical record refer that until 150 years ago the forest physiognomy was like overaged coppice with standards of oak. At those time the forest was irregularly and occasionally logged and the grazing was transhumant and periodically suspended. Actually, the woodland is grazed by several domestic animals which, at various trophic levels, play an important role in favouring and shaping the floristic composition of the herbaceous vegetation. The authorizations for grazing was granted by municipality board to farmers of neighbourhood without any control on the number of livestock and grazing system. The entire study area is, in fact, subject to grazing year round; according to official data from the Orgosolo municipality, the average livestock pressure in 2003 was 1.7 LU (adult livestock unit) per hectare, of which more than $70 \%$ are sheep, $14 \%$ swine, and the rest divided among cattle, goats and equines (Campus 2005). Shading, nitrification, and selection of species less palatable to animals have favoured the presence of thorny species (Genista pichi-sermolliana, G. corsica, Carlina corymbosa, Centaurea calcitrapa, Ononis spinosa, Ptilostemon casabonae) or toxic species (Euphorbia cupani, Paeonia morisii, Digitalis purpurea, Ranunculus spp.). Prominent among the ruderal and the nitrophilus species are Onopordon illyricum, Urtica atrovirens and U. pilulifera and the endemic Rumex suffocatus. The presence of Rubus ulmifolius is quite remarkable, because although browsed by sheep and especially goats, it partially characterises an anomalous undergrowth, together with dogrose (Rosa canina) which rises in big tufts. Other woody species are wild pear (Pyrus spinosa) and hawthorn (Crataegus monogyna), found sporadically throughout the area. Exploitation, practiced regularly for centuries, as testified by the important archaeological remains of the nuraghic era, has selected a number of species of scarce foraging and grazing interest. The species of the genus Aira, Vulpia, Bromus are the most common among the gramineae, whereas among the compositae the genus Crepis, Reichardia and Carlina are those which give a significant contribution to the grass turf. Among the leguminosae, in addition to the above-mentioned Ononis spinosa, two species are of remarkable pabular interest: Lotus alpinus, exclusively in the high mountain areas of the Gennargentu and the Marghine-Goceano region of Sardinia, but most of all Trifolium subterraneum, which protects itself from overgrazing thanks to its self-reseeding character. Present among the labiatae are thyme
(Thymus catharinae) and helichrysum (Helichrysum microphyllum), small fragrant suffrutexes usually associated with gorses. Asphodel (Asphodelus microcarpus) is sporadically browsed in its vegetative stage, but completely rejected during flowering; this facilitates its diffusion, which is also helped by its root system, very rich in nourishing supplies. Similar to asphodel, geophytes provided with tubers, bulbs and rhizomes have an advantage, particularly those of the genus Gagea, Scilla, Ornithogalum, and Leucojum, which also produce showy and characteristic flowerings.

The whole area is crossed by paths open to lorry traffic which favours channelled erosion, as they interrupt the already poor grass turf, compact the soil and constitute preferential path for run off concentration. This process has considerably increased in recent years, adding to the actions of the swine, which are present in far greater number with respect to the sustainability of the area, and dig looking for tubers, bulbs and larvae, thus worsening the deterioration of the entire area.

The flora of the Pradu woodland, despite being poor in species suitable for grazing, has an endemic component common to the other areas of the Gennargentu which increases its environmental value.

\section{Plot Sampling}

The research area was delimited and georeferenced using regional orthophotographs (1998) on a scale of 1:10 000 in a GIS environment. The total area was divided into a squared $100 \mathrm{~m}$ wide grid following the Gauss-Boaga geographic projection; the area of each square was further divided into 25 smaller $20 \mathrm{~m}$ wide squares $\left(400 \mathrm{~m}^{2}\right)$, also referred to as the reticule. Next were the stratification of the big squares according to the degree of canopy cover in the GIS environment ( 3 classes: $\mathrm{A}<30 \%, 31<\mathrm{B}<60 \%$ and $\mathrm{C}>60 \%$ ), and the random selection of 45 small squares (specimen areas - SA) in proportion to the frequency observed in each cover class.

\section{Field Observations}

For each SA the general characteristics such as slope, exposure, and degree of vegetation cover were recorded. The crown height $(\mathrm{H})$, as well as the bigger measurement (L1)

Tab. 1 - Mean density of shrubs $\left(\mathrm{N} \mathrm{ha}^{-1} \pm\right.$ standard error) for the 45 sample squares.

\begin{tabular}{lcccc}
\hline \multirow{2}{*}{ Species } & \multicolumn{3}{c}{ Tree canopy cover classes } & \multirow{2}{*}{ Overall } \\
\cline { 2 - 4 } & $\mathbf{3 0 \%}$ & $\mathbf{3 0 - 6 0 \%}$ & $>\mathbf{6 0 \%}$ & \\
\hline Stachys glutinosa & $81( \pm 0.7)$ & $100( \pm 15.8)$ & $75( \pm 0.5)$ & $100( \pm 14.1)$ \\
Crataegus monogyna & $56( \pm 0.2)$ & $25( \pm 0.5)$ & $50( \pm 2.4)$ & $47( \pm 4.1)$ \\
Genista pichi-sermolliana & $996( \pm 387.2)$ & - & - & - \\
Prunus spinosa & $46( \pm 0.2)$ & $38( \pm 2.6)$ & $25( \pm 0.5)$ & $42( \pm 4.2)$ \\
Rubus ulmufolius & $152( \pm 1.8)$ & $175( \pm 19.3)$ & $68( \pm 12.1)$ & $135( \pm 34.6)$ \\
\hline
\end{tabular}

and the one perpendicular to it (L2), were taken for each shrub present.

Every seedling of tree species (height $<5$ $\mathrm{m})$ was surveyed distinguishing between those growing in the open and those growing among shrubs, and its height (h) was also measured; in the presence of groups of seedlings, the total number (ns) and the height of the tallest saplings were taken.

Finally, in a random sample of shrubs with seedlings, 50 of these were taken, and their height (h), and the collar diameter (d) were measured. Seedling age was estimated by counting the annual rings using a stereomicroscope.

\section{Data Processing}

The area occupied by the crown of each shrub (S) was estimated through the ellipse formula (eqn. 1):

$$
S=\frac{\pi \cdot L 1 \cdot L 2}{4}
$$

As a whole and for each shrub species, we determined the number of shrubs per hectare $\left(\mathrm{N} \mathrm{ha}^{-1}\right)$, the average occupied area and the average height. For the seedling sample we also calculated the average yearly increase in height (Ih) and diameter (Id).

All data were elaborated using common tests of inferential statistics:

- $\chi^{2}$ test to assess the differences between the shrub species for the presence or absence of seedlings within (in cases of just 1 degree of freedom Yates's correction was utilized);

- two-way ANOVA (factorial scheme with interaction) for the variables $\mathrm{S}, \mathrm{H}, \mathrm{h}$ (variation sources: shrub species; presence or absence of seedlings);

- one-way ANOVA for the variables S (variation source: tree cover degrees) and $h$ (variation source: shrub species);

- Duncan's test in all cases where $\mathrm{P}<0.05$;

- analysis of the regression of h, d, Ih, Id versus the age of the seedlings;

- linear correlation between S, H and h;

- Spearman's correlation between S, H and the number of seedlings (ns).

\section{Results}

\section{Shrubs}

An overall census of 502 shrubs with an average density of 279 (s.e. \pm 73.5 ) per hec- 


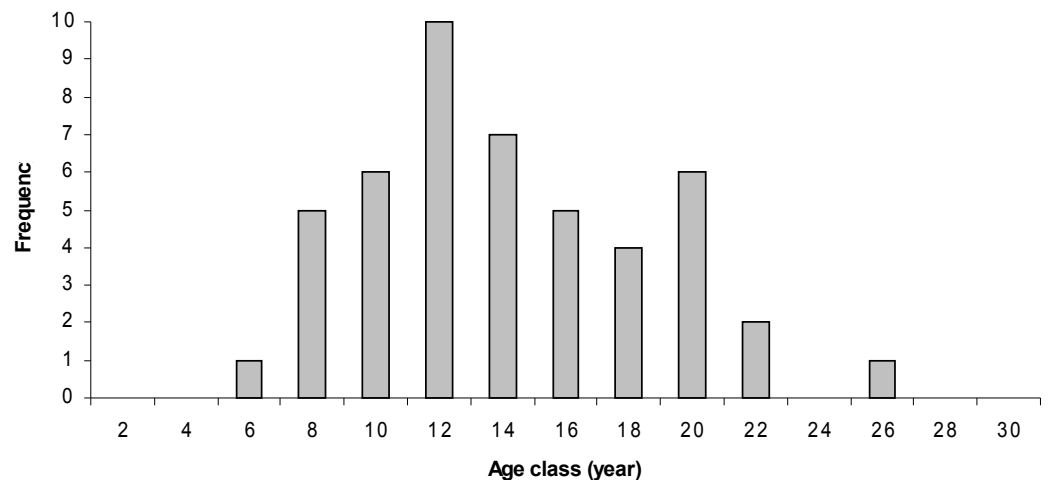

Fig. 1 - Distribution of seedlings in age classes (2 years amplitude).

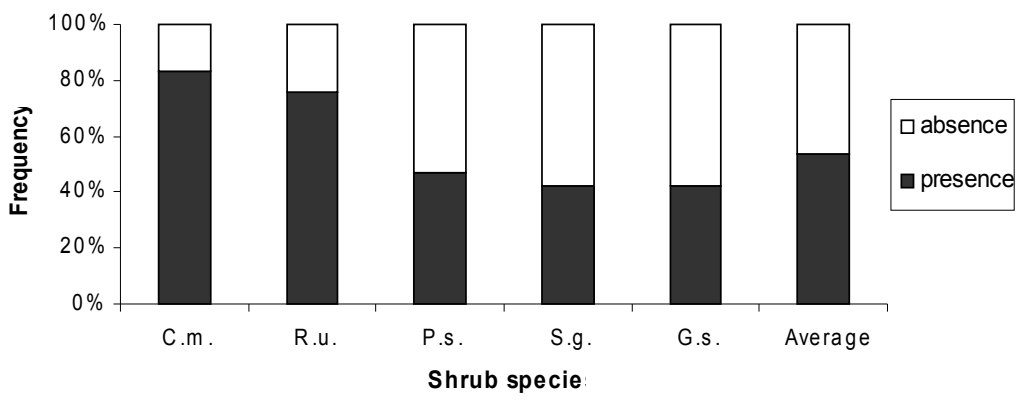

Fig. 2 - Frequency of shrubs with or without saplings.

Tab. 2 - Comparison among sapling densities inside the different shrub species (n.s.= not significant).

\begin{tabular}{lccc}
\hline \multicolumn{1}{c}{ Comparisons } & d.f. & $\boldsymbol{\chi}^{2}$ & P \\
\hline 1. All species & 4 & 59.1 & $<0.01$ \\
2. C.m. vs. R.u. & 1 & 1.1 & n.s. \\
3. P.s. vs. G.s. vs. S.g. & 2 & 0.13 & n.s. \\
4. 2 vs. 3 & 1 & 58.4 & $<0.01$ \\
\hline
\end{tabular}

Tab. 3 - ANOVA test, variable $S$, variation sources are shrub species (1), the presence or absence of seedlings (2) and the interaction $1 \times 2$ (n.s. $=$ not significant).

\begin{tabular}{lcrc}
\hline \multicolumn{1}{c}{ Effect } & d.f. & F & P \\
\hline 1. Shrub species & 4 & 17.35 & $<0.001$ \\
2. Sapling occurrence & 1 & 7.15 & $<0.01$ \\
3. Interaction 1x2 & 4 & 1.55 & n.s. \\
Error & 492 & & \\
\hline
\end{tabular}

Tab. 4 - ANOVA test, variable $\mathrm{H}$, variation sources are shrub species (1), the presence or absence of seedlings (2) and the interaction $1 \times 2$ (n.s. $=$ not significant).

\begin{tabular}{lccc}
\hline \multicolumn{1}{c}{ Effect } & d.f. & F & P \\
\hline 1. Shrub species & 4 & 15.8 & $<0.001$ \\
2. Sapling occurrence & 1 & 1.45 & n.s. \\
3. Interaction 1x2 & 4 & 0.13 & n.s. \\
Error & 492 & & \\
\hline
\end{tabular}
monogyna (C.m.); Genista pichi-sermolliana (G.s.); Prunus spinosa (P.s.); Rubus ulmifocally subject to waterlogging and presumably unsuitable for woody plants.

In the remaining 37 specimen areas the following shrub species were registered (Tab. 1): Stachys glutinosa (S.g.), Crataegus 1 standard error). lius (R.u.). The most abundant species are G.s. (56\%) and R.u. (29\%) followed by C.m. (7\%), S.g. (5\%) and P.s. (3\%). G.s. is exclusive to the cover class $\mathrm{A}$, where the average density of shrubs is higher (443 plants ha ${ }^{-1}$; s.e. \pm 3.8$)$. This density generally decreases with the increase of the degree of tree cover.

The average area of the shrub crown, with the exclusion of G.s. which has an area of $2.6 \mathrm{~m}^{2}$, is not significantly differentiated in the various classes of tree cover $\left(\mathrm{F}_{2: 218}=1.48\right)$ and is on average $1.3 \mathrm{~m}^{2}$ (s.e. \pm 0.12 ).

\section{Saplings}

The total number of registered seedlings comes to 1079 , with an average density of 599 (s.e. \pm 122 ) per ha; Holm oak is the most abundant species $(92 \%)$ with 553 (s.e. \pm 117 ) seedlings per hectare, whereas Downy oak $(8 \%)$ is much less present ( $46 \pm 18$ seedlings per hectare).

The average age of the seedlings is 14 years (s.e. \pm 0.6 ) ranging from 6 to 25 years; the subdivision of the sampled individuals into age classes (Fig. 1) reveals a normal distribution with a slight asymmetry towards the right side.

The height of the seedlings $(48 \mathrm{~cm}$; s.e. \pm 18 ) is not significantly correlated to their age $(\mathrm{r}=0.2)$; on the contrary d $(1 \mathrm{~cm}$; s.e. \pm 0.4$)$ is positively correlated to this feature $(\mathrm{r}=0.7$, $\mathrm{p}<0.01$ ). The mean $\mathrm{Ih}$ is $3.9 \mathrm{~cm} /$ year (s.e. \pm 0.4 ) and tends to decrease considerably with age $(\mathrm{r}=-0.68, \mathrm{p}<0.01)$, the average Id is $0.7 \mathrm{~cm} /$ year (s.e. \pm 0.04 ), with no significant correlation to age.

\section{Interaction between shrubs and saplings} (shrub facilitation)

Fifty-five percent of the shrubs were shown to host saplings (Fig. 2, Tab. 2) with significant differences among species $\left(\chi_{[4]}^{2}=59.1\right.$, $\mathrm{p}<0.01$ ).

C.m. is the species with the highest frequency of patches containing saplings $(83 \%)$ with values comparable to those of R.u. (76

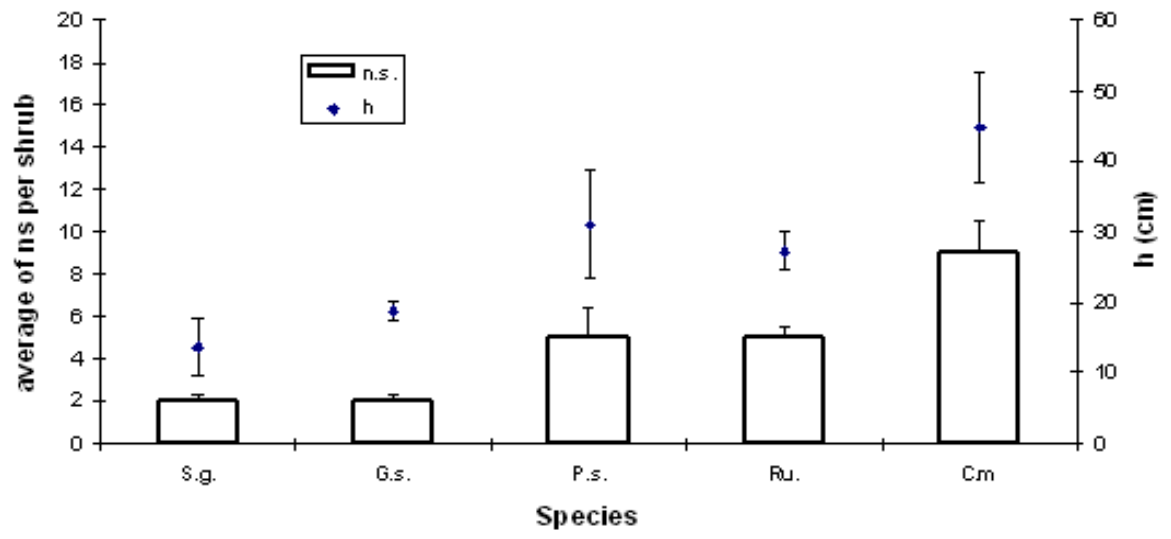

Fig. 3 - Means of sapling number (ns) and shrub height (h) by species (vertical bars indicate 
Tab. 5 - Values of the Spearman correlation between $\mathrm{H}, \mathrm{S}$ and ns. $(*)=\mathrm{P}<0.05 ;(* *)=$ $\mathrm{P}<0.01)$.

\begin{tabular}{lccr}
\hline \multicolumn{1}{c}{ Species } & H & S & $\begin{array}{r}\text { N. of } \\
\text { cases }\end{array}$ \\
\hline S.g. & 0.40 & -0.12 & 10 \\
P.s. & -0.04 & 0.15 & 29 \\
G.s. & 0.06 & 0.19 & 119 \\
Ru. & $0.48^{* *}$ & $0.46^{* *}$ & 7 \\
C.m. & $0.66^{* *}$ & $0.81^{* *}$ & 110 \\
Total & $0.32^{*}$ & $0.23^{*}$ & 275 \\
\hline
\end{tabular}

$\% ; \chi_{[1]}^{2}=1.1$; all in all, the other kinds of shrubs have significantly lower values with respect to the previous ones $\left(\chi_{[1]}^{2}=58.4\right.$, $\mathrm{p}<0.01)$, with comparable frequencies $\left(\chi_{[2]}^{2}\right.$ $=0.13$ ) though consistently below $45 \%$.

The ANOVA test (Tab. 3) has highlighted significant differences with respect to the average area (S), both among the examined species and regarding the presence or absence of saplings inside.

On the basis of the results of the Duncan test, G.s. has an average area $\left(2.6 \mathrm{~m}^{2}\right)$ considerably larger than S.g. $\left(0.2 \mathrm{~m}^{2}\right)$ and P.s. $\left(0.8 \mathrm{~m}^{2}\right)$, whereas R.u. and C.m. have intermediate values (1.4 and $1.9 \mathrm{~m}^{2}$ respectively); moreover, the shrubs giving shelter to saplings have a larger average area than the others ( 2.5 and $1.5 \mathrm{~m}^{2}$ respectively).

The ANOVA test (Tab. 4) showed significant differences with respect to the average $\mathrm{H}$ among species.

Based on the results of the Duncan test, the average height of C.m. shrubs $(1.34 \mathrm{~m})$ is higher than that of all other shrubs, those of P.s. and S.g. are the lowest $(0.41$ and $0.29 \mathrm{~m}$ respectively), whereas R.u. and G.s. have intermediate heights $(0.82$ and $0.83 \mathrm{~m}$ respectively).

Considering all shrubs with saplings inside, the average ns (Fig. 3) varies considerably among the species $\left(\mathrm{F}_{4 ; 270}=11.67, \mathrm{p}<0.01\right)$; from the Duncan test it appears that C.m. has a higher average ns (9), whereas G.s. and S.g. have the lowest (2), and P.s. and R.u. have intermediate values (5).

The average height of the saplings $(24 \pm$ $1.4 \mathrm{~cm}$ ) varies quite considerably among the

Tab. 6 - Values of the linear correlation between $\mathrm{h}, \mathrm{H}$ and $\mathrm{S} .\left({ }^{*}\right)=\mathrm{P}<0.05 ;(* *)=\mathrm{P}$ $<0.01)$.

\begin{tabular}{lllr}
\hline \multicolumn{1}{c}{ Species } & h-H & h-S & $\begin{array}{r}\text { N. of } \\
\text { cases }\end{array}$ \\
\hline S.g. & $0.66^{*}$ & 0.47 & 10 \\
P.s. & 0.72 & 0.04 & 29 \\
G.s. & $0.33^{*}$ & $0.35^{* *}$ & 119 \\
R.u. & $0.57^{* *}$ & $0.58^{* *}$ & 7 \\
C.m. & $0.81^{* *}$ & $0.68^{* *}$ & 110 \\
Total & $0.60^{* *}$ & $0.28^{* *}$ & 275 \\
\hline
\end{tabular}

shrub species $\left(\mathrm{F}_{4 ; 270}=5.31, \mathrm{p}<0.01\right)$. In particular, the Duncan test shows that the average $\mathrm{h}$ is higher for C.m. $(44.8 \mathrm{~cm})$, lower for S.g. and G.s. (13.7 and $18.8 \mathrm{~cm}$ respectively), whereas R.u. and P.s. have intermediate values $(27.3$ and $31 \mathrm{~cm})$.

The number of saplings per shrubs is positively correlated (Tab. 5) to the $\mathrm{S}$ and $\mathrm{H}$ of the shrubs $(r=0.23$ and 0.32 respectively, $\mathrm{p}<0.05$ ), but the correlation is very high and significant for R.u. $(r=0.46$ and 0.48 respectively, $\mathrm{p}<0.01)$ and for C.m. $(\mathrm{r}=0.81$ and 0.66 respectively, $\mathrm{p}<0.01$ ).

The height of the saplings is positively correlated to $\mathrm{S}$ and most of all to $\mathrm{H}(\mathrm{r}=0.28$ and 0.6 respectively, $\mathrm{p}<0.01)$. The highest correlation values are those of C.m. and R.u. (Tab. 6).

\section{Discussion}

\section{Shrubs}

At present the shrub cover consists of five main species and represents a minor part $(12 \%)$ of the total ground cover, compared to grass $(31 \%)$ and bare soil $(57 \%)$. Over half of the registered shrubs are Genista $(56 \%)$; they form very dense patches located in areas with large granitic outcrops, thus indicating a preference for relatively scant pedological conditions (more dryness). Rubus ulmifolius is the second most common shrub species (29\%), followed by Crataegus monogyna (7\%) Prunus spinosa and Stachys glutinosa (3\% and $5 \%$ respectively), both were distributed quite homogeneously over the examined area. All these shrub species have thorns basically as a result of the selecting action of animal grazing (Todd \& Hoffman 1999, Vesk \& Westoby 2001). It is a known fact that in environments with a Mediterranean climate, excessive grazing pressure initially causes a simplification of biodiversity with the disappearance of the most palatable species and/or the substitution of perennial herbaceous species. The last regression stage is the complete disappearance of vegetation and the beginning of erosive phenomena (Peco et al. 2006).

The density and composition of the shrub cover in the Pradu woodland are clearly connected with tree cover: where the latter is higher, the shrub cover is minimal. This condition is largely ascribable to the ecological needs of the shrub species, all of which are basically heliophilus; the action of animal grazing, however, also influences their distribution, which tends to thicken in the less browsed areas and in the presence of large rock outcrops.

\section{Seedlings}

The specific composition of regeneration is directly related to the species proportion of the tree layer: in fact, Holm oak seedlings are the most common $(80 \%)$ and are occa- sionally associated with those of the Downy oak $(17 \%)$ which is sometimes the only species present inside the shrubs. Under no circumstances has the regeneration of Montpellier maple been observed.

The light microclimate inside small shrub patches is known as a potential selecting factor for the saplings of tree species (Franco-Pizaña et al. 1996, Kunstler et al. 2006). In our case, the higher shade tolerance of Holm oak compared to Downy oak and Montpellier maple could facilitate its survival inside shrubs. Moreover, the morphology of seedling leaves should also add competitive advantages to Holm oak: under conditions of repeated/continuous grazing the leaf tends to become more coriaceous and thorny, expressing a substantial adaptability to grazing (Bernetti 1995).

The age of the saplings is undoubtedly a very important factor within the Pradu woodland. As in other studies carried out in the Mediterranean region (Callaway \& Davis 1998, Pulido et al. 2001), our observations have demonstrated that a general, uneven age distribution exists; a shortage of young and very young subjects is reported, however. More specifically, the sampled individuals are rather old and their age class distribution shows some peaks that might be the consequence of years of larger seed production. In such years, in fact, the population of predators leaves a higher number of seeds available for germination (Sork et al. 1993, Crawley \& Long 1995, Murphy \& Janzen in Bellocq et al. 2005). The absence of seedlings younger than 6 years of age could be symptomatic of a tendency towards a worsening of the seed quality produced by the plants: according to Cierjacks \& Hensen (2004), increased grazing pressure results in a higher percentage of aborted Holm oak acorns. However, worsening climatic conditions (dryness) should not be ruled out.

According to Smit et al. (2007) the facilitating action exerted by shrubs on tree regeneration decreases as biotic stress increases: intensive grazing causes severe damage to shrubs, thus leading to heavier grazing and higher seedling mortality. The yearly average height growth of the seedlings $(3.9 \mathrm{~cm})$ decreases considerably with the increase in age $(r=-0.7, p<0.01)$ as a result of livestock browsing; nonetheless, the diameter growth remains constant $(0.7 \mathrm{~cm} /$ year $)$, thus confirming that oak species tolerate grazing well (Shaw 1974 and Hilton et al. 1987, in Mitchell \& Kirby 1990, Williams et al. 2006).

\section{Shrubs Facilitation}

In the Pradu woodland, shrub patches represent the only habitats where processes of natural regeneration of the tree components have been observed: no seedlings have been found in the open. This result confirms that 
facilitation is especially important in cases of heavy grazing pressure (Bertness \& Callaway 1994). However, the fact that no regeneration has been observed in many shrubs could indicate that intensive grazing causes severe damage even to shrubs and reduces their defensive action (Smit et al 2007).

The interaction between shrubs and tree regeneration occurs in different ways during the various stages of the regeneration process (Franco-Pizaña et al. 1996, Smit et al. 2006). Due to their morphological characteristics and to the richness of nourishing supplies, the seeds of oak species are more likely to be consumed (Shaw 1968, Barik et al. 1996). The same authors highlight the role played by rodents and birds in the dispersal of these seeds: among them, the jay (Garrulus glandarius) appears abundant in the study area (Shenk \& Torre in Camarda 1993). The dispersal of seeds from the parent plants and their establishment in small repositories thanks to these "secondary dispersal agents" become more important when the number of safe sites is small (Pulido 2002). It has been widely confirmed that shrub patches are very important sites both in the dispersal phase (Bossema 1979, Debussche \& Isenmann 1994, Franco-Pizaña et al. 1996, Callaway \& Davis 1998, Rousset \& Lepart 1999) and in the establishment phase, since seeds and seedlings are protected from predation and trampling (Herrera 1995, Rousset \& Lepart 1999, Kuiters \& Slim 2003, Smit et al. 2005, Smit et al. 2007). This role remains consistent even if seed consumption by insects, rodents and birds reaches significant levels (Leiva \& Fernández-Alés 2003, Smit et al. 2006, Williams et al. 2006). Moreover, the shrub patches create the most favourable micro environmental conditions for the germination of seedlings (Gómez-Aparicio et al. 2005b, Gómez-Aparicio et al. 2005c): less soil compaction, higher humidity, less radiation, greater availability of nutrients, and less competition with herbaceous species (Callaway 1992, Franco-Pizaña et al. 1996, Rousset \& Lepart 1999, Chambers 2001, Bakker et al. 2004, Gómez-Aparicio et al. 2005a, Kunstler et al. 2006).

As observed in research conducted in Holland (Bakker et al. 2004), the size of the shrubs has an influence on the seedlings' chance of survival. Our results indicate that at this stage the height of the shrubs does not affect the establishment of seedlings. On the contrary, the crown area is a decisive factor; the wider the shrubs, the greater the difficulty for animals (especially swine) to feed on acorns and browse seedlings. At Pradu the minimum effective area has proven to be somewhat larger than $2 \mathrm{~m}^{2}$; there are, however, species-related differences, with the cover of Crataegus monogyna and Rubus ulmifolius representing the safest site for the establishment of seedlings. A minor portion of Genista pichi-sermolliana shrubs has seedlings inside, but the seedling density is nevertheless low. This may be due to the scarce massiveness of the crown of this species, with a greater accessibility to animals compared to previous ones; however, it must also be considered that Genista patches concentrate on rock outcrops, which have more adverse edaphic conditions for seed development and are generally located away from the most vigorous seed-bearer trees.

Prunus spinosa and Stachys glutinosa are not very common and generally form smallsized shrubs less effective in facilitating the establishment of seedlings.

In the consolidation stage the survival and growth of the seedlings are mainly influenced by animal browsing (Mitchell \& Kirby 1990, Callaway \& D'Antonio 1991, Callaway 1992, Gill 1992, Buckley et al. 1998, Rousset \& Lepart 1999, Kuiters \& Slim 2003, Bakker et al. 2004, Castro et al. 2006, Smit et al. 2007). Competition between shrubs and saplings for light, water and nutrients is also important at this stage, and, according to some authors, results in reduced growth of tree species (Buckley et al. 1998, Rousset \& Lepart 2000).

The average height of saplings at Pradu is considerably greater in shrubs of Crataegus monogyna, Prunus spinosa and Rubus ulmifolius compared to the other species; nevertheless no sampling has reached such a size as to definitely escape browsing action by livestock (roughly estimated within $2 \mathrm{~m}$ ).

Seedlings have shown the tendency to parallel the height growth of the hosting shrubs; this correlation is particularly marked in the case of Crataegus monogyna. This phenomenon is probably due to the morphological characteristics of hawthorn which, in optimum conditions and unlike Prunus spinosa, is able to grow in height at the same rate of the saplings. Shrubs of Rubus ulmifolius tend to grow enveloping seedlings and follow them in their growth; since young shoots of this plant are susceptible to grazing, the height growth is, nonetheless, conditioned. Studies conducted in California (Williams et al. 2006) have also shown that shrubs of Rubus discolor facilitate the establishment of seedlings of oak species; however, they interfere with their subsequent development by confining their growth.

At Pradu, the seedlings' growth inside Genista pichi-sermolliana patches, though proportional to the shrubs' size, is less marked: this could be due both to the poor conditions of the site where these shrubs grow and to the poor ability of this species to protect itself from grazing. Clefts between rocks occasionally proved to be safe sites for the establishment and survival of seedlings of tree species; this phenomenon has already been described for Picea abies seedlings in the timbered grasslands of Switzerland (Smit et al. 2005). Still our observations indicate that saplings remain confined inside the rock clefts with no chance for further growth, both because of punctual animal browsing as soon as the seedlings emerge, and because of the poor soil condition of such microenvironments.

\section{Conclusions}

The effectiveness of the interaction between shrubs and seedlings with respect to tree species regeneration in wooded pastures has been demonstrated at the Pradu site as well. In particular, shrub facilitation has proved to be species-specific (Callaway \& Walker 1997, Callaway 1998, Gómez-Aparicio et al. 2005a). Crataegus monogyna is the most efficient species in facilitating the establishment and development of tree species seedlings; Rubus ulmifolius is efficient in the establishment phase, but somewhat less so in the following stages. The other shrubs species have a weaker facilitating role.

Despite the fact that the density of shrubs hosting Holm oak or Downy oak seedlings is quite considerable, the high average age and the small size of the seedlings lead us to think that the present grazing pressure is incompatible with any concrete chance of consolidation for these saplings, and thus for the natural regeneration of the tree component of this peculiar ecosystem. At present, most of the shrubs and the hosted saplings have not attained a height greater than the browsing line of cattle and equines; this means that their future is still dubious.

At the same time, the local social and economic situation does not allow us to advance any hypothesis about even a temporary suspension of grazing activities; as a result, the survival of these ecosystems seems unlikely, and there are important economic, hydrologic and aesthetic implications. A great cultural heritage, based on the local population's management of natural resources over the centuries, risks extinction as well. The conservation of these stands must therefore rely on the rationalisation of human activities through the exploitation of a whole range of resources (not least tourist appeal). This approach appears to be the only way to face this threat and effectively solve the problem of tree regeneration at Pradu.

The adjustment of the grazing pressure to sustainable levels is certainly a critical measure. According to recent studies conducted in $Q$. ithaburensis forests in Israel (DufourDror 2007), a cattle density of 0.7 head per hectare is already able to cause considerable damage to regeneration. It is obvious that an agreement must be reached with local breeders, perhaps by compensating the reduced yield with a better profitability of dairy and meat products. Another possibility could be the introduction of systems that 
provide for the integration of natural regeneration by means of planting seedlings either inside natural shrub patches, as positively experimented in Spain for $Q$. pirenaica (Castro et al. 2004, Castro et al. 2006), or inside special enclosures.

\section{Acknowledgements}

This work was conducted with the cooperation of the Orgosolo municipality (Nuoro province). The authors would like to thank Prof. Ignazio Camarda of the University of Sassari, for his assistance with the floristic classification. Special thanks also go to Dr. Tonina Muggianu and Dr. Nicola Sanna for their contribution to field surveys. The experiments comply with the current laws of the country in which they were performed.

\section{References}

Alias S, Bianchi L, Calamini G, Campus S, Gregori G (2008). Pascoli arborati in Sardegna. Un caso in provincia di Nuoro. Sherwood 141: 15-19.

Arrigoni PV (1968). Fitoclimatologia della Sardegna. Webbia 23: 1-100.

Bakker ES, Olff H, Vandenberghe C, de Maeyer

K, Smit R, Gleichman JM, Vera FWM (2004). Ecological anachronisms in the recruitment of temperate light-demanding tree species in wooded pastures. Journal of Applied Ecology 41 571-582. - doi: 10.1111/j.0021-8901.2004.00908.

Barik SK, Tripathi RS, Pandey HN, Rao P (1996) Tree regeneration in a subtropical humid forest: effect of cultural disturbance on seed production, dispersal and germination. Journal of Applied Ecology 33 (6): 1551-1560. - doi: 10.2307/ 2404793

Bellocq MI, Jones C, Dey DC, Turgeon JJ (2005). Does the shelterwood method to regenerate oak forest affect acorn production and predation? Forest Ecology and Management 205: 311-323. doi: 10.1016/j.foreco.2004.10.013

Bernetti G (1995). Selvicoltura Speciale. UTET Editore, Torino, Italy.

Bertness MD, Callaway R (1994). Positive interactions in communities. Trends in Ecology \& Evolution 9 (5): 191-193. - doi: 10.1016/01695347(94)90088-4

Bianchi L, Calamini G, Gregori E, Zorn G (2003). Valutazione degli effetti del rimboschimento in zone aride della Sardegna. Inquadramento climatico delle aree sperimentali. Italia Forestale e Montana 5: 389-407.

Bossema I (1979). Jays and oaks: an eco-ethological study of a symbiosis. Behaviour 70: 1-17. doi: 10.1163/156853979X00016

Buckley DS, Sharik TL, Isebrands JG (1998). Regeneration of northern red oak: positive and negative effects of competitor removal. Ecology 79 (1): 65-78. - doi: 10.1890/0012-9658(1998)079 [0065:RONROP]2.0.CO;2

Callaway RM (1992). Effect of shrubs on recruitment of Quercus douglasii and Quercus lobata in California. Ecology 73 (6): 2118-2128. - doi:
$10.2307 / 1941460$

Callaway RM, D’Antonio CM (1991). Shrub facilitation of coast live oak establishment in central California. Madrono 38 (3): 158-169.

Callaway R, Walker LR (1997). Competition and facilitation: a synthetic approach to interactions in plant communities. Ecology 78 (7): 19581965. - doi: 10.1890/0012-9658(1997)078[1958: CAFASA]2.0.CO;2

Callaway RM (1998). Are positive interactions species-specific? Oikos 82 (1): 202-207. [online] URL: http://www.jstor.org/stable/3546931

Callaway RM, Davis FW (1998). Recruitment of Quercus agrifolia in central California: the importance of shrub-dominated patches. Journal of Vegetation Science 9 (5): 647-656. - doi: $10.2307 / 3237283$

Camarda I (1993). Montagne di Sardegna. Carlo Delfino editore, Sassari, Italy.

Campus S (2005). Il bosco di Pradu, Orgosolo (NU). B. Sc. Thesis in Forest and Environmental Sciences, DISTAF, Università di Firenze, Italy. Castro J, Zamora R, HÏdar JA, GÏmez JM, GÏmezAparicio L (2004). Benefits of using shrubs as nurse plants for reforestation in mediterranean mountains: a 4-year study. Restoration Ecology 12 (3): 352-358. - doi: 10.1111/j.10612971.2004.0316.x

Castro J, Zamora R, Hódar JA (2006). Restoring Quercus pyrenaica forests using pioneer shrubs as nurse plants. Applied Vegetation Science 9: 137-142. - doi: 10.1658/1402-2001(2006)9[137: RQPFUP]2.0.CO;2

Chambers JC (2001). Pinus monophylla establishment in an expanding pinus-juniperus woodland: environmental conditions, facilitation and interacting factors. Journal of Vegetation Science 12: 27-40. - doi: 10.2307/3236671

Cierjacks A, Hensen I (2004). Variation of stand structure and regeneration of Mediterranean holm oak along a grazing intensity gradient. Plant Ecology 173: 215-223. - doi: 10.1023/ B:VEGE.0000029322.75004.ad

Crawley MJ, Long CR (1995). Alternate bearing, predator satiation and seedling recruitment in Quercus robur 1. The Journal of Ecology 83 (4): 683-696. - doi: 10.2307/2261636

Debussche M, Isenmann P (1994). Bird-dispersed seed rain and seedling establishment in patchy Mediterranean vegetation. Oikos, 69 (3): 414426. - doi: 10.2307/3545854

Diaz M, Pulido FJ, Marañon T (2003). Diversidad biológica y sostenibilidad ecológica y económica de los sistemas adehesados. Ecosistemas 2003

Dufour-Dror JM (2007). Influence of cattle grazing on the density of oak seedlings and saplings in a tabor oak forest in Israel. Acta Oecologica 3 (1): 223-228. - doi: 10.1016/j.actao.2006.11.003

Franco-Pizaña JG, Fulbright TE, Gardiner DT, Tipton AR (1996). Shrub emergence and seedling growth in micro environments created by Prosopis glandulosa. Journal of Vegetation Science 7 (2): 257-264. - doi: 10.2307/3236326

Gill RMA (1992). A review of damage by mammals in north temperate forests: 3. Impact on trees and forests. Forestry 65: 363-388. - doi: 10.1093/forestry/65.4.363-a

Gómez-Aparicio L, Gómez JM, Zamora R, Boettinger JL (2005a). Canopy vs. Soil effects of shrubs facilitating tree seedlings in mediterranean montane ecosystems. Journal of Vegetation Science 16: 191-198. - doi: 10.1111/j.16541103.2005.tb02355.x

Gómez-Aparicio L, Valladares F, Zamora R, Quero JL (2005b). Response of tree seedlings to the abiotic heterogeneity generated by nurse shrubs: an experimental approach at different scales. Ecography 28: 757-768. - doi: 10.1111/ j.2005.0906-7590.04337.x

Gómez-Aparicio L, Gómez JM, Zamora R $(2005 \mathrm{c})$. Microhabitats shift rank in suitability for seedling establishment depending on habitat type and climate. Journal of Ecology 93: 11941202. - doi: 10.1111/j.1365-2745.2005.01047.x

Gómez JM, Hódar JA, Zamora R, Castro J, García D (2001). Ungulate damage on Scots pines in mediterranean environments: effects of association with shrub. Can. J. Bot. 79 (6): 739-746. doi: 10.1139/cjb-79-6-739

Herrera J (1995). Acorn predation and seedling production in a low-density population of Cork oak (Quercus suber 1.). Forest Ecology and Management 76: 197-201. - doi: 10.1016/03781127(95)03566-S

Joffre R, Vacher J, De Los Llanos, Long G (1988). The dehesa: an agrosilvopastoral system of the Mediterranean region whit special reference to the Sierra Morena area of Spain. Agroforestry System 6: 71-96.

Joffre R, Rambal S, Ratte JP (1999). The dehesa system of southern Spain and Portugal as a natural ecosystem mimic. Agroforestry Systems 45: 57-79. - doi: 10.1023/A:1006259402496

Kuiters AT, Slim PA (2003). Tree colonisation of abandoned arable land after 27 years of horsegrazing: the role of bramble as a facilitator of oak wood regeneration. Forest Ecology and Management 181: 239-251. - doi: 10.1016/S03781127(03)00136-1

Kunstler G, Curt T, Bouchaud M, Lepart J (2006). Indirect facilitation and competition in tree species colonization of sub-mediterranean grasslands. Journal of Vegetation Science 17: 379388. - doi: 10.1111/j.1654-1103.2006.tb02458.x Leiva MJ, Fernández-Alés R (2003). Post-dispersive losses of acorn from mediterranean Savannalike forests and shrublands. Forest Ecology and Management 176: 265-271. - doi: 10.1016/ S0378-1127(02)00294-3

Linares AM (2007). Forest planning and traditional knowledge in collective woodlands of Spain: the dehesa system. Forest Ecology and Management 249: 71-79. - doi: 10.1016/j.foreco.2007. 03.059

Madrau S (1995). Valutazione della attitudine all'utilizzo forestale dei suoli della Sardegna. L'area del parco del Gennargentu. Annali Accademia Italiana di Scienze Forestali 44: 279-305.

Mitchell FJG, Kirby KJ (1990). The impact of large herbivores on the conservation of semi-natural woods in the British uplands Forestry 63: 333- 353. - doi: 10.1093/forestry/63.4.333 
Munoz DC (2004). Algunos apuntes para la conservaciòn de las dehesas. Escuela Tecnica Superior De Ingeneros Agronomos Y De Montes. Univeridad De Cordoba, Spain.

Peco B, Sánchez AM, Azcárate FM (2006). Abandonment in grazing systems: consequences for vegetation and soil. Agriculture, Ecosystems and Environment 113: 284-294. - doi: 10.1016/ j.agee.2005.09.017

Perevolotsky A, Seligman NG (1998). Role of grazing in mediterranean rangeland ecosystem. Bioscience 48 (12): 1007-1017. - doi: 10.2307/ 1313457

Plieninger T (2005). Compatibility of livestock grazing with stand regeneration in mediterranean holm oak park lands. Journal for Nature Conservation 15: 1-9. - doi: 10.1016/j.jnc.2005.09.002

Plieninger T, Modolell Y, Mainou J, Konold W (2004). Land manager attitudes toward management, regeneration, and conservation of Spanish holm oak Savannas (Dehesas). Landscape and Urban Planning 66: 185-198. - doi: 10.1016/ S0169-2046(03)00100-2

Pulido FJ (2002). Biología reproductiva y conservación: el caso de la regeneración de bosques templados y subtropicales de robles (Quercus spp.). Rev. Chil. Hist. Nat. 75 (1): 5-15. - doi: 10.4067/S0716-078X2002000100002

Pulido FJ, Díaz M, Hidalgo De Trucios SJ (2001).
Size structure and regeneration of Spanish holm oak Quercus ilex forests and dehesas: effects of agroforestry use on their long-term sustainability. Forest Ecology and Management 146: 1-13. doi: 10.1016/S0378-1127(00)00443-6

Rivas-Martínez S, Rivas-Sáenz S(2008). Sistema de clasificación bioclimática mundial, 19962009, Centro de Investigaciones Fitosociológicas, España. [online] URL: http://www.ucmes/info/cif

Rousset O, Lepart J (1999). Shrub facilitation of Quercus humilis regeneration in succession on calcareous grasslands. Journal of Vegetation Science 10 (4): 493-502. - doi: 10.2307/3237184

Rousset O, Lepart J (2000). Positive and negative interactions at different life stages of a colonizing species (Quercus humilis). Journal of Ecology 88: 401-412. - doi: 10.1046/j.1365-2745.2000. 00457.x

Shaw MW (1968). North Wales: A preliminary study of acorn production, viability and losses. The Journal of Ecology 56 (2): 565-583. - doi: $10.2307 / 2258251$

Smit C, Béguin D, Buttler A, Müller-Schärer H (2005). Safe sites for tree regeneration in wooded pastures: a case of associational resistance? Journal of Vegetation Science 16: 209-214. - doi: 10.1111/j.1654-1103.2005.tb02357.x

Smit C, Gusberti M, Müller-Schärer H (2006).
Safe for saplings; safe for seeds? Forest Ecology and Management 237: 471-477. - doi: 10.1016/j.foreco.2006.09.069

Smit C, Vandenberghe C, Den Ouden J, MüllerSchärer H (2007). Nurse plants, tree saplings and grazing pressure: changes in facilitation along a biotic environmental gradient. Oecologia 152: 265-273. - doi: 10.1007/s00442-006-0650-6 Soil Survey Staff (2006). Keys to soil taxonomy $\left(10^{\text {th }}\right.$ edn). United States Department of Agriculture, Natural Resources Conservation Service.

Sork VL, Bramble J, Sexton O (1993). Ecology of mast-fruiting in three species of north American deciduous oaks. Ecology 74 (2): 528-541. - doi: $10.2307 / 1939313$

Todd SW, Hoffman MT (1999). A fence-line contrast reveals effects of heavy grazing on plant diversity and community composition in Namaqualand, South Africa. Plant Ecology 142: 169-178. - doi: 10.1023/A:1009810008982

Vesk PA, Westoby M (2001). Predicting plant species' responses to grazing. Journal of Applied Ecology 38: 897-909. - doi: 10.1046/j.13652664.2001.00646.x

Williams K, Westrick LJ, Williams BJ (2006). Effects of blackberry (Rubus discolor) invasion on oak population dynamics in a California savanna. Forest Ecology and Management 228: 187-196. doi: 10.1016/j.foreco.2006.03.002 